\title{
In Vitro Shoot Initiation in Kentucky Coffeetree
}

\author{
R.L. Geneve, S.T. Kester, and S. El-Shall ${ }^{1}$ \\ Department of Horticulture and Landscape Architecture, University of \\ Kentucky, Lexington, KY 40546
}

Additional index words. tissue culture, shoot elongation, gibberellic acid, Gymnocladus dioicus

Kentucky coffeetree (Gymnocladus dioicus L.) is a large dioecious tree suited for specimen use in the landscape. It is welladapted to a wide range of soil conditions, tolerates drought, and performs well in the urban environment. The present study was initiated to study the possibility of providing a system for tissue-culture propagation of the Kentucky coffeetree.

Explants were prepared from 2-month-old seedlings grown under standard greenhouse conditions and mature explants were selected from local trees $\approx 20$ years old. Explants consisted of newly emerged and rapidly expanding stems. Seedling and mature explants were surface-disinfected by rinsing the leafless stems in running tap water for $1 \mathrm{hr}$. This was followed by sequentially treating the stems for $20 \mathrm{sec}$ in $70 \%$ ethanol followed by $5 \mathrm{~min}$ in $1.5 \mathrm{mg}$ benomyl $/ \mathrm{ml} \mathrm{H}_{2} \mathrm{O}$. Stems were finally placed for $15 \mathrm{~min}$ in $0.5 \% \mathrm{NaOCl}$ containing $0.1 \%$ Alconox detergent, were agitated and then rinsed three times in autoclave deionized water. Three node explants were aseptically prepared and placed in $25 \times 150$-mm test tubes or Magenta GA7 vessels. All cultures were maintained at 25 $\pm 2 \mathrm{C}$ with a 16-hr photoperiod of 60 $\mu \mathrm{mol} \cdot{ }^{-1} \cdot \mathrm{m}^{-2}$ provided by cool-white fluorescent lamps.

Seedling explants were placed in either woody plant medium (WPM) (Lloyd and McCown, 1980) or a modified WPM supplemented with benzylaminopurine (BAP) at $0,5,10$, or $20 \mu \mathrm{M}$. Gibberellic acid (GA,) at 5 or $10 \mu \mathrm{M}$ in combination with 5 and 10 $\mu \mathrm{M}$ BAP was tested for its effect on shoot elongation on modified WPM. WPM was modified by replacing $\mathrm{K}_{2} \mathrm{SO}_{4}$ with $\left(\mathrm{NH}_{4}\right)_{2} \mathrm{SO}_{4}$ (132 mg.liter ${ }^{-1}$ ) and $\mathrm{KNO}_{3}\left(202 \mathrm{mg} \cdot\right.$ liter $^{-1}$ ) and increasing $\mathrm{CaCl}_{2} \cdot \mathrm{H}_{2} \mathrm{O}$ and $\mathrm{KH}_{2} \mathrm{PO}_{4}$ to

Received for publication 26 May 1989. Kentucky Agricultural Experiment Station paper 8-10-104. The cost of publishing this paper was defrayed in part by the payment of page charges. Under postal regulations, this paper therefore must be hereby marked advertisement solely to indicate this fact. ${ }^{1}$ Visiting Scientist, Horticulture Research Institute, Cairo, Egypt.
202 and $408 \mathrm{mg} \cdot$ liter $^{-1}$, respectively.

Mature explants were placed on a medium containing $10 \mu \mathrm{M}$ BAP and the short shoots that developed were excised from the original explant and placed on a medium with modified WPM medium containing 0,5 , or $10 \mu \mathrm{M}$ GA, with or without $10 \mu \mathrm{M}$ BAP.

Seedling explants developed shoots in vitro in response to BAP (Table 1). There was no significant effect of growing medium on shoot initiation (data not shown) but there was a significant effect of BAP concentration. Greatest shoot length was observed at 5 and $10 \mu \mathrm{M}$ BAP. Typically, seedling explants initiated one to five shoots. However, only one of these shoots continued to develop and elongate. This shoot apparently showed dominance over the other shoots on the explant. Removal of the dominant shoot released another shoot to elongate and this shoot subsequently exhibited dominance over the remaining short shoots or buds. Rarely would a culture have two shoots $>10 \mathrm{~mm}$ in length. Explants on the modified WPM showed less phenolic exudation into the medium and this medium was used for all subsequent experimentation.

Giberellic acid has been used successfully to elongate in vitro shoots of several woody species (Bennett and Davies, 1986; Economou and Spanoudaki, 1986). In vitro shoots of Kentucky coffeetree responded to $\mathrm{GA}_{3}$ by increasing the shoot length of the dominant shoot, but failed to increase the number of explants with more than one microshoot per culture $>10 \mathrm{~mm}$ in length.

Mature explants initiated multiple shoots on a medium containing $10 \mu \mathrm{M}$ BAP. However, mature explants failed to produce shoots $>10 \mathrm{~mm}$ (Fig. 1). After the first subculture, there was an increase in the number of shoots initiated by mature explants. Initial explants produced 1.5 compared to 4.9 shoots per explant after the first subculture. Addition of $\mathrm{GA}_{3}$ to the medium did not affect shoot elongation. In cultures of 'Bradford' pear (Pyrus calleryana Decne. 'Bradford'), there was an 8-month lag period between the isolation of explants and rapid shoot initiation and development (Stimart and Harbage, 1989). This
Table 1. Shoot initiation in seedling explants of Kentucky coffeetree after 60 days of exposure to various concentrations of benzylamino purine (BAP) when grown on modified woody plant medium.

\begin{tabular}{llcc} 
& \multicolumn{3}{c}{ Shoots } \\
\cline { 2 - 4 } $\begin{array}{l}\text { BAP concn } \\
(\mu \mathrm{M})\end{array}$ & Mean no. & $\begin{array}{c}\text { Mean } \\
\text { length }(\mathrm{mm})\end{array}$ & $\begin{array}{c}\text { Mean no. } \\
>10 \mathrm{~mm}\end{array}$ \\
\hline 0 & $1.2(0.2)^{2}$ & $2.9(0.8)$ & 0.0 \\
5 & $1.5(0.2)$ & $9.1(2.1)$ & 0.7 \\
10 & $2.3(0.3)$ & $8.1(1.9)$ & 0.6 \\
20 & $3.3(0.4)$ & $5.8(1.1)$ & 0.6 \\
\hline${ }^{\text {Means }} \pm(95 \%$ confidence interval) $\mathrm{N}=30$.
\end{tabular}

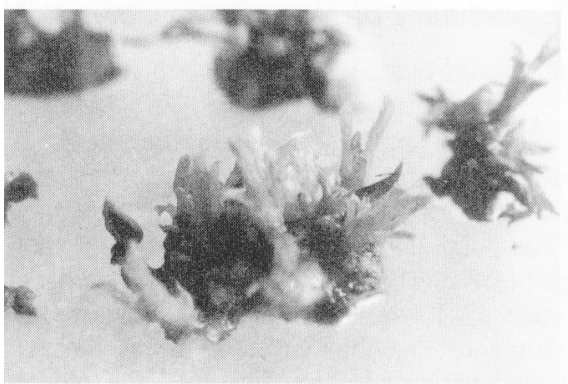

Fig. 1. Multiple shoot initiation in a mature explant of Kentucky coffeetree after three subcultures.

delay has not been observed for Kentucky coffeetree. Explants have been separated and subculture for 1 year and continue to initiate shoots that fail to elongate.

Microshoots from seedling explants were rooted readily after treatment with $537 \mu \mathrm{M}$ NAA (50\% ethanol) as a basal dip for $2 \mathrm{~min}$ and placed in a closed plastic container with a medium of 1 peat : 1 vermiculite $(\mathrm{v} / \mathrm{v})$. Mature explants failed to produce microshoots of sufficient length that could be tested for root initiation potential.

Micropropagation of Kentucky coffeetree was possible with seedling explants. Mature explants could be successfully established in vitro, but were unable to exhibit significant shoot elongation in vitro under the conditions employed during this study.

\section{Literature Cited}

Bennett, L.K. and F.T. Davies, Jr. 1986. In vitro propagation of Quercus schumardii seedlings. HortScience 21(4):1045-1047.

Economou, A.S. and M.J. Spanoudaki. 1986. The influence of cytokinins and gibberellic acid on gardenia tissue cultures. Scientia Hort. 29:155161.

Lloyd, G. and B. McCown. 1980. Commercially feasible micropropagation of mountain laurel, Kalmia latifolia, by usc of shoot-tip culture. Comb. Proc. Intl. Plant Prop. Soc. 30:421-427.

Stimart, D.P. and J.F. Harbage. 1989. In vitro shoot proliferation of Pyrus calleryana from vegetative buds. HortScicnce 24(2):298-299. 